\title{
METODE DAN PENDEKATAN PEMBUKTIAN WUJUD TUHAN: Studi Pemikiran Muhammad Iqbal dan Bediuzzaman Said Nursi
}

\author{
Maftukhin dan Akhmad Rizqon Khamami \\ IAIN Tulungagung \\ E-mail: rizqonkham@yahoo.com
}

\begin{abstract}
This article examines the approach of Muhammad Iqbal and Bediuzzaman Said Nursi in proving the form of God. Their approaches come in the mindset of the invasion of atheism and the philosophy of materialism. Both thinkers use different approaches. While Iqbal uncovered arguments of God from the aspect of epistemology and offered arguments for religious experience, Nursi used the teleological argument utilizing the development of science. Nursi used the form of God arguments inherited from earlier scholars to strike at the attacks of atheism and materialism. Whereas Iqbal used a philosophical approach learned from Western scientists. On the other hand, when Iqbal uncovered from an aspect of philosophy, Nursi used simple language to appeal to ordinary people by presenting teleological arguments in the form of stories, dialogues, analogies, arguments for natural order, and impossible arguments. These two thinkers use a different approach, but both of them use science as the basis of their arguments. Nursi used the latest findings of science in his day to reinforce the arguments he raised, while Iqbal used the epistemology of science to manifest God.
\end{abstract}

Artikel ini mengupas pendekatan Muhammad Iqbal dan Bediuzzaman Said Nursi dalam pembuktian wujud Tuhan. Pendekatan kedua pemikir tersebut lahir di tengah serbuan ateisme dan filsafat materialisme. Kedua pemikir tersebut melakukan perlawanan terhadap ateisme dan materialisme 
dengan pendekatan berbeda. Iqbal membongkar argumen wujud Tuhan dari aspek epistemologi, dan menawarkan argumen pengalaman beragama. Sedangkan Nursi menggunakan argumen teleologi dengan memanfaatkan perkembangan sains pada masa itu. Nursi menggunakan argumen wujud Tuhan yang diwarisi dari para ulama terdahulu untuk menghantam serangan kelompok ateisme dan penganut materialisme. Sedangkan Iqbal menggunakan pendekatan filsafat yang dipelajari dari ilmuwan Barat. Di sisi lain, ketika Iqbal membongkar dari aspek filsafat, Nursi menggunakan bahasa yang sederhana untuk menarik masyarakat awam dengan menghadirkan argumen teleologi dalam bentuk cerita, dialog, analogi, argumen keteraturan alam, dan argumen kemustahilan. Meskipun kedua pemikir ini menggunakan pendekatan berbeda, akan tetapi keduanya samasama menggunakan sains sebagai dasar argumentasinya. Nursi menggunakan temuan terbaru sains pada zamannya untuk memperkuat argumen yang ia munculkan, sedangkan Iqbal menggunakan epistemologi sains untuk wujud Tuhan.

Keywords: Bediuzzaman Said Nursi; cosmological argument; Muhammad Iqbal; ontology argument; teleological argument

Received: August 13, 2018; Accepted: November 8, 2018

\section{Pendahuluan}

Cara untuk mengetahui wujud Tuhan adalah melalui seorang rasul. Lewat rasul dan nabi, wahyu Tuhan disampaikan kepada umat manusia. Ketika nabi dan rasul masih berada di tengah masyarakat, cara memahami Tuhan dan wahyu-Nya adalah cukup dengan bertanya secara langsung. Pada saat nabi tidak ada lagi, pertanyaan yang muncul, bagaimana manusia dapat mengetahui wujud Tuhan? Setelah berakhirnya masa kenabian, umat manusia berada di ruang kosong yang hanya diisi oleh rasio. Karena itu, salah satu cara untuk mengetahui wujud Tuhan adalah dengan pembuktian rasional. Para filsuf membangun argumen rasional untuk membuktikan bahwa Tuhan betul-betul ada.

Sejauh ini muncul tiga argumen dalam pembuktian wujud Tuhan, yaitu argumen kosmologi, argumen ontologi, dan argumen teleologi. Ketiga argumen tersebut lazim dipakai untuk mengartikulasikan pemahaman rasional tentang Tuhan sebelum sains berkembang pesat. Metode pembuktian rasional dipakai secara umum di dunia Islam abad 
pertengahan. Ilmu kalam pada abad pertengahan dipenuhi dengan ketiga argumen ini. Sejak abad pertengahan hingga memasuki abad modern, para pemikir dan filsuf Muslim mengulang-ulang pembuktian yang sama tentang wujud Tuhan tanpa memberi kebaruan yang berarti. Pada waktu yang bersamaan, di Barat, David Hume dan Emmanuel Kant melakukan kritik terhadap metode pembuktian klasik. Kelak di tangan pengikut filsafat materialisme, kritikan kedua filsuf tersebut dijadikan bahan untuk menyerang agama, terutama wujud Tuhan. Kemunculan buku Dialogues Concerning Natural Religion oleh David Hume dan On the Origin of Species oleh Charles Darwin memperkuat serangan tersebut. Jika pendekatan Hume lebih berwarna filsafat, maka Darwin menggunakan pendekatan sains. Hume dan Darwin sama-sama menentang konsep penciptaan alam oleh Tuhan.

Ketika di Barat pada era modern bersamaan dengan perkembangan sains, wujud Tuhan mendapat penentangan, lantas bagaimana tanggapan pemikir Muslim pada era modern tersebut? Artikel ini akan membahas dua pemikir Muslim yang hidup di era yang dipenuhi dengan sains, materialisme, positivisme, dan ateisme, yaitu Muhammad Iqbal (1877-1938 M) dan Bediuzzaman Said Nursi (1876-1960 M). Dua pemikir Islam ini hidup di masa yang hampir bersamaan meskipun berasal dari dua negara Muslim yang berbeda. Iqbal dari anak benua India, sedangkan Said Nursi dari Turki. Pertanyaan yang dikupas dalam artikel ini, bagaimana metode dan pendekatan kedua pemikir Muslim ini dalam mempertahankan argumen wujud Tuhan, terutama di tengah-tengah kemajuan sains saat itu? Dengan menggunakan pendekatan komparasi, penulis melihat bahwa masing-masing pemikir ini menawarkan pendekatan berbeda atas problem zamannya. Asumsi penulis, jika Iqbal mempertanyakan seluruh argumen rasional pembuktian wujud Tuhan dan menawarkan argumen pengalaman beragama, di pihak lain Nursi memakai argumen teleologi.

Ditemukan sejumlah tulisan membandingkan pemikiran Iqbal dan Nursi yang menunjukkan urgensitas pemikiran keduanya. Maftukhin mengupas reposisi konsep ketuhanan keduanya saat menghadapi perkembangan sains. Jika Iqbal menawarkan konsep ketuhanan panenteisme, maka Nursi justru memelihara konsep ketuhanan model alAsh'ariyyah. Di dalam perbandingan ini dijelaskan bahwa Iqbal melakukan rekonstruksi epistemologi, sedangkan Nursi bekerja pada aspek ontologi (Maftukhin 2017). Sementara itu, perbandingan tentang konsep kenabian mendapat perhatian dari Mahsheed Ansari, dan disusul kemudian dengan 
tulisannya tentang perbandingan pandangan antara Iqbal dan Nursi tentang dimensi metafisik mi'râj (Ansari 2015; Ansari 2017). Di sisi lain, tanggapan keduanya terhadap modernitas dikupas oleh Nuriye Aksoy. Dijelaskan bahwa kedua pemikir Muslim era modern tersebut melihat modernitas sebagai tantangan baru umat Islam (Aksoy 2015). Selain itu, konsep takdir kedua pemikir tersebut mendapat perhatian Yasien Mohamed. Pada saat takdir dilihat oleh Iqbal sebagai upaya manusia sendiri, Nursi memahami takdir dengan kacamata pemikiran al-Ash'ariyyah (Mohamed 2006). Di luar beberapa perbandingan di atas, cara pandang Iqbal dan Nursi tentang argumen wujud Tuhan belum terbahas. Artikel ini mengupas pendekatan Iqbal dan Nursi dalam argumen wujud Tuhan ketika menghadapi serangan ateisme dan filsafat materialisme di tengah perkembangan sains modern. Sebelum mengupas pendekatan Iqbal dan Nursi, terlebih dahulu dibahas mengenai penggunaan argumen wujud Tuhan di kalangan pemikir Muslim abad pertengahan untuk mendapatkan gambaran yang lebih jelas.

\section{Argumen Wujud Tuhan pada Abad Pertengahan}

Pembahasan mengenai wujud Tuhan mendapat penguatan melalui argumen kosmologi. Argumen ini untuk pertama kali diperkenalkan oleh Aristoteles. Pada prinsipnya, argumen kosmologi didasarkan pada konsep penggerak pertama. Setiap gerak pastilah digerakkan oleh gerak sebelumnya, dan gerak sebelumnya tersebut pastilah hasil dari gerak lain yang ada lebih dulu, dan begitu seterusnya. Pada gerak paling awal harus ada penggerak pertama, yaitu sosok penggerak yang menyebabkan kemunculan gerak yang tidak digerakkan oleh gerak yang lain. Itulah Tuhan. Aristoteles menyatakan bahwa Tuhan adalah penggerak pertama. Selanjutnya, premis argumen kosmologi digubah menjadi pernyataan yang menegaskan bahwa setiap kejadian harus memiliki penyebab, dan tiap sebab harus memiliki penyebab lainnya, dan begitu seterusnya. Karena itu, muncul dua pilihan: yaitu, regresi tak berkesudahan dari sebab, atau harus ada titik awal sebagai penyebab pertama. Menurut Aristoteles, regresi tak berkesudahan adalah mustahil. Harus ada penyebab pertama. Penyebab pertama itu pastilah Tuhan (Politis 2005, 260-97). Argumen ini kemudian diadopsi oleh al-Kindî.

Al-Kindî (801-873 M) adalah filsuf pertama di dunia Islam yang menggunakan argumen kosmologi (dalîl al-hudûth). Ia menuangkan argumen ini ke dalam buku Fî al-Falsafat al-Ûlâ. Salah satu argumen yang 
dimunculkan al-Kindî adalah pembahasan tentang prinsip determinasi (tarjîh). Sebelum alam raya ini muncul, timbul dua kemungkinan, yaitu bisa ada atau tidak ada. Namun pada kenyataannya, alam ada. Untuk keberadaannya, alam membutuhkan sosok Penyebab (muhdith) yang memulai dunia dari ketiadaan, ex nihilo. Penyebab ini haruslah tidak diciptakan karena Dia adalah penyebab bagi segala yang ada. Penyebab tersebut tidak lain adalah Tuhan. Untuk meneguhkan keberadaan Tuhan, al-Kindî menyatakan bahwa hanya Tuhan saja yang tunggal. Segala sesuatu selain Tuhan adalah hasil komposisi. Tuhan tidak bermateri, tidak berbentuk, tidak punya kualitas, dan tidak punya kuantitas. Tuhan tidak dapat dimasukkan ke dalam kategori apapun. Tuhan tidak punya genus. Tuhan bersifat kekal (Fakhry 2004, 71-95).

Pemikiran yang hampir sama dapat dijumpai pada Ibn Sînâ (981$1037 \mathrm{M}$ ), yang merupakan filsuf besar dan tokoh utama dalam filsafat peripatetik (mashâiyyah) (Al-Walid 2018, 2). Dalam hal ini, ia memunculkan argumen ontologi. Ibn Sînâ menegaskan bahwa Tuhan adalah sosok yang wajib ada. Karena Tuhan sebagai wâjib al-wujûd tidak memiliki genus, maka sosok-Nya dan perbuatan-Nya tidak dapat menjadi objek pemikiran diskursif. Alasannya, karena Ia tanpa sebab. Selain itu, Tuhan tidak memiliki sifat, dan bahkan Tuhan tidak memiliki esensi di luar eksistensiNya. Esensi Tuhan sama dengan eksistensi-Nya. Tuhan adalah sosok di mana eksistensi dan esensi berada secara bersamaan. Karakteristik Tuhan ini mendapat penolakan dari kalangan Muslim ortodoks yang melihat karakteristik tersebut tidak sesuai dengan ajaran Islam; bagaimana mungkin Tuhan disebut Maha Tahu jika Ia tidak memiliki sifat? Ibn Sînâ menjawab, Tuhan mampu mengetahui segala sesuatu karena semua berasal dari emanasi-Nya. Namun, karena Tuhan tidak memiliki pengetahuan persepsiinderawi, Tuhan tidak mengetahui hal-hal partikular dan hanya mengetahui prinsip universal. Akan tetapi, lanjut Ibn Sînâ, hal ini tidak menghalangi Tuhan untuk mengetahui suatu kejadian. Kemampuan kreatif Tuhan terhubung dengan alam intelektual-Nya, dan kemampuan tersebut mengalir secara eternal dari rasio Tuhan. Meskipun alam semesta berposisi sebagai entitas yang mandiri, tetapi eksistensinya masih bergantung pada Tuhan (Nasr 1978, 198-214).

Pemikiran tentang kekekalan alam di atas dapat dianggap sebagai Islamisasi pemikiran Aristoteles oleh Ibn Sînâ. Pendapat Ibn Sînâ tentang kekekalan alam tidak diterima oleh Muslim ortodoks. Salah satu penolaknya adalah al-Ghazâlî. Ia menolak pendapat Ibn Sînâ yang 
menyebutkan bahwa Tuhan dan alam adalah dua hal yang berbeda dan tidak saling berinteraksi. Al-Ghazâlî juga tidak puas dengan argumen penyebab pertama al-Kindî. Ia beralasan bahwa tidak ada yang mengharuskan adanya penyebab pertama semata-mata karena alasan deduktif murni. Secara teori, regresi tak berkesudahan bisa saja terjadi. Dengan bantahan ini, ia meruntuhkan premis argumen kosmologi tentang keharusan adanya penyebab pertama (al-Ghazâlî 1963, 90-91).

Sama seperti al-Ghazâlî, beberapa filsuf Barat modern menolak argumen kosmologi. Immanuel Kant merupakan salah satu di antaranya. Ia menolak pembuktian kosmologi dengan alasan bahwa argumen kosmologi tidak lain sekedar argumen ontologi (logika murni) yang terselubung. Argumen kosmologi dinilai kurang lebih sama seperti argumen ontologi, hanya saja minus premis empiris. Meski begitu, argumen al-Kindî di atas dimunculkan kembali pada abad keduapuluhsatu oleh seorang ilmuwan Barat bernama William Craig (Craig 2000). Argumen ini dikenal dengan nama "argumen kalam." Alam, menurut argumen ini, harus memiliki permulaan. Selain al-Ghazâlî, penolakan terhadap argumen kosmologi dan ontologi di dunia Islam diikuti oleh Muhammad Iqbal.

\section{Pendekatan Muhammad Iqbal}

Di mata Iqbal, argumen kosmologi dianggap tidak kokoh karena dibangun di atas pemahaman yang dangkal terhadap karakter realitas empiris. Argumen tersebut justru merefleksikan realitas yang saling bertentangan. Pertentangan ini menyebabkan kontradiksi internal pada argumen tersebut. Munculnya kekurangan argumen kosmologi, menurut Iqbal, tidak saja karena dipenuhi kontradiksi pada dirinya, tetapi karena mengingkari pengalaman beragama. Sebagai argumen klasik, argumen kosmologi merupakan warisan dari pemikiran filsafat yang muncul pada era sebelum kelahiran sains modern. Meskipun memberi kontribusi yang tidak sedikit, namun argumen ketuhanan prasains ini hanyalah produk filsafat dari zamannya. Menurut Iqbal, satu-satunya jalan untuk menutupi kekurangan argumen kosmologi adalah dengan menggabungkan empirisme sains dengan Alquran. Iqbal berpendapat, pemahaman tentang Tuhan hendaknya tidak didasarkan atas kategori filosofis yang diperoleh dari pemikiran spekulatif semata, tetapi haruslah berangkat dari deskripsi realitas dengan menggunakan pendekatan sains dan Alquran.

Dalam perspektif Iqbal, Tuhan dipahami sebagai Yang Tak Terbatas, sedangkan alam dipahami sebagai sesuatu yang terbatas. 
Ketakterbatasan Tuhan adalah intensif, bukan ekstensif. Alasan Iqbal, agar manusia tidak terjerumus ke dalam sikap panteistik yang menganggap Tuhan sebagai elemen kosmik. Ketakterbatasan Tuhan tidak diartikan sebagai kekuatan kosmik yang impersonal, namun sebagai aktualisasi terusmenerus. Tuhan memanifestasikan diri-Nya dalam aktivitas kreatif yang tidak ada henti-hentinya. Memahami ketakterbatasan Tuhan dalam terma ekstensif mengantarkan kita untuk menyifati karakter Tuhan sebagai impersonal. Sebaliknya, memahami ketakterbatasan dalam terma intensif mendorong untuk menyifati karakter Tuhan sebagai Sosok yang Berkesadaran. Cara baca Iqbal ini sejalan dengan metafora di dalam Alquran. Cahaya dipakai sebagai metafora untuk menggambarkan Tuhan. Fisika modern menegaskan bahwa kecepatan cahaya tidak terkalahkan oleh entitas apapun. Cahaya digunakan untuk menggambarkan wujud Tuhan agar terhindar dari penafsiran panteistik (Iqbal 1986, 51).

Akan tetapi karena alam merupakan manifestasi aktivitas kreatif Tuhan, maka alam memiliki potensi tidak terbatas karena kapasitas kreatif Tuhan bersifat tidak terbatas. Jika alam merupakan sunnatullah yang memiliki kapasitas tidak terbatas, maka wajar jika karakteristik ketakterbatasan juga dimiliki oleh alam. Fisika modern menyatakan bahwa alam mengalami proses dinamis, yaitu tumbuh dan berkembang. Jadi, kita tidak memberikan karakteristik kepada Tuhan sebagai kekuatan kosmik yang tidak terbatas secara ekstensif, namun Tuhan adalah individu yang terlibat dalam aktivitas kreatif yang tiada henti. Tuhan memiliki karakteristik personal yang termanifestasi dalam segala hal yang Ia ciptakan (Iqbal 1986, 52). Dalam pembahasan filsafat agama, konsep ketuhanan versi Iqbal ini masuk ke dalam kategori panenteisme (Maftukhin 2017, 80).

Setelah mengkritik argumen kosmologi, selanjutnya Iqbal melancarkan kritik terhadap argumen teleologi. Awalnya, argumen teleologi dipopulerkan oleh William Paley melalui buku Natural Theology. Paley menghadirkan perumpamaan tentang arloji. Diandaikan, seseorang sedang berjalan di tengah gurun tiba-tiba menemukan sebuah arloji. Pertanyaan yang timbul, bagaimana benda ini bisa ada? Akan terpikir oleh orang tersebut, arloji ini muncul bukan karena kebetulan, tetapi karena didesain dan dibuat oleh seorang perancang. Dengan analogi yang sama, Paley berargumen bahwa alam semesta yang sangat tertata dan teratur ini adalah bukti adanya sosok perancang. Karena keteraturan luar biasa pada alam semesta dari galaksi hingga sel tubuh alam ini pastilah memiliki Perancang yang Cerdas. Iqbal mengkritik argumen Paley. Antara arloji dan alam 
semesta merupakan dua hal berbeda. Tidak seperti arloji di mana pembuatnya meletakkan mesin dari sesuatu yang telah ada, alam berasal dari materi yang diciptakan oleh Tuhan sendiri.

Menurut Iqbal, argumen kosmologi dan teleologi memiliki kedekatan. Keduanya sama-sama diwarnai dualisme sebab-akibat meskipun dengan titik tekan berbeda. Argumen teleologi melihat 'akibat' (alam semesta) dengan tidak berhenti semata-mata pada kesimpulan adanya 'sebab' (Tuhan), tetapi meneliti 'akibat' untuk menyibak karakter 'sebab' tersebut. Argumen teleologi tampaknya ingin menghindari perangkap dualisme sebab-akibat sebagaimana halnya argumen kosmologi. Akan tetapi dalam analisa Iqbal, dualisme itu tetap ada dan tersembunyi di dalam argumen ini. Iqbal melihat argumen teleologi telah gagal. Alasan kegagalan argumen teleologi ini, di mata Iqbal, adalah karena konsepsi hubungan antara Tuhan dan alam didasarkan pada analogi bikinan pikiran manusia. Teleologi memberi kita hanya perancang, bukan sosok pencipta (Iqbal 1986, 33).

Selain itu, Iqbal menolak cara pandang mekanis yang menyatakan bahwa masa depan sudah tercetak. Waktu dianggap tidak bekerja, kita hanya bertemu dengannya. Gerak waktu semata-mata hanya menjadi tempat berputarnya naskah drama yang tidak memiliki kaitan apapun dengan takdir. Anggapan waktu sebagai gerak kreatif dinilai tidak memiliki makna apapun. Sebaliknya, Iqbal menjelaskan bahwa Alquran menganggap waktu sebagai salah satu simbol kebesaran Tuhan. Hubungan antara waktu dan Tuhan dapat dibaca melalui satu hadis yang berbunyi, "Janganlah kamu mengutuk waktu, karena waktu adalah Tuhan."

Jika sejauh ini diyakini takdir sebagai kondisi tercatat sejak zaman pra-keabadian, Iqbal memahami takdir dengan membuang jauh-jauh karakteristik predetermisme. Menurut pemikiran tradisional, segala penyebab adalah Tuhan, dan 'akibat' dipandang sebagai penerima pasif dari takdir yang telah ditentukan. Dalam hal takdir, Iqbal membongkar dualisme antara sebab dan akibat dengan mengungkap hubungan reflektif keduanya. Maksudnya, ketika 'akibat' (manusia) didahului oleh Penyebab (Tuhan), bukan berarti bahwa 'akibat' sudah ditakdirkan, namun ia memiliki masa depan yang terbuka dengan segala kemungkinan baru. Salah satu dari kemungkinan itu adalah bahwa 'akibat' beraktualisasi dengan segala potensi di dalam dirinya. Misalnya, manusia selalu bergerak untuk mengubah nasib dan ia tidak sekedar menjadi akibat saja. Meski begitu manusia masih dalam status ketundukan kepada kehendak Sang Penyebab. 
Bagaimana dengan doa yang dipanjatkan manusia? Melalui doa, manusia berupaya untuk mengubah aksi Sang Penyebab. Artinya, manusia menjadi sebab bagi Sang Penyebab untuk mengabulkan doanya (Iqbal 1986, 10).

Setelah mengkritik argumen kosmologi dan teleologi, Iqbal mengalihkan perhatiannya pada argumen ontologi. Seperti diketahui, argumen ontologi dalam filsafat Barat diperkenalkan oleh Descartes. Argumen ontologi menggunakan semata-mata akal murni. Argumen ontologi menyatakan bahwa tidak bisa tidak Tuhan harus ada. Keharusan adanya Tuhan dapat kita tangkap sebagaimana kita memahami sudut segitiga pastilah berjumlah 180 derajat. Ringkasnya, mustahil memikirkan Tuhan tanpa Ia ada. Iqbal menolak argumen yang mendasarkan pada semata-mata logika murni (Iqbal 1986, 37). Iqbal mengupas argumen Descartes dengan kritis. Argumen tersebut didasarkan pada dualisme antara idealisme (jiwa) dan realisme (realitas empiris) dengan karakteristik kesempurnaan disematkan kepada idealisme, sedangkan realisme dianggap tidak sempurna.

Menurut Iqbal, problem argumen ontologi dapat diselesaikan dengan menghilangkan dualisme tersebut. Pertanyaan muncul, manakah yang lebih utama, apakah alam idealis yang tidak berubah dan kekal, ataukah dunia realis? Iqbal menjawab, jiwa sebagai representasi alam idealis telah ada sebelum waktu dan ruang. Karena mempunyai sisi efisien dan apresiatif, jiwa sebagai ego memiliki kehendak untuk mengatakan "inilah aku.” Bahkan Iqbal menggambarkan Tuhan sebagai Ego Tertinggi. Sebagai Ego, Tuhan memiliki karakteristik wajib berubah. Biologi modern menyatakan bahwa perubahan adalah salah satu karakteristik yang melekat pada segala sesuatu yang hidup. Alquran menggambarkan Tuhan tidak hanya sebagai Pemberi Hidup, tetapi juga sebagai Yang Maha Hidup. Dengan menggabungkan biologi dan Alquran, Iqbal berpendapat, Tuhan Yang Maha Hidup adalah Yang Maha Berubah. Tetapi, menurut Iqbal, perubahan itu terjadi dalam waktu murni yang termanifestasi dalam aktivitas kreatif Tuhan. Iqbal menolak pandangan yang mengatakan bahwa kesempurnaan berarti tidak mengalami perubahan. Perubahan pada Tuhan merupakan cara Tuhan mengungkapkan diri. Pengungkapan diri ini memunculkan segala sesuatu selain diri-Nya, meliputi antara lain materi, ruang, waktu, atom, batu, sel, tumbuhan, pohon, burung, binatang, dan lain-lain (Iqbal 1986, 48).

Jika argumen kosmologi, ontologi dan teleologi memiliki kekurangan, lantas argumen apa yang dipakai untuk membuktikan wujud 
Tuhan? Iqbal memunculkan argumen pengalaman beragama. Bagi Iqbal, bentuk keimanan yang otentik adalah hasil dari pengalaman diri seseorang. Argumen pengalaman beragama bukan merupakan argumen analitis, dan tidak mendasarkan pada logika murni maupun empiris. Argumen ini berbasis intuisi. Prinsip epistemologi Islam sebagaimana dijelaskan dalam Alquran menyebutkan bahwa pengetahuan diperoleh melalui tiga metode: antara lain, persepsi-inderawi ('ayn al-yaqin), yaitu pengetahuan yang didapat dari empiris; kognitif ('ilm al-yaqin), yaitu pengetahuan dari rasio murni; dan pengalaman absolut (haqq al-yaqîn), yaitu pengetahuan intuisi. Dari pengetahuan intuisi ini lahirlah argumen pengalaman beragama. Iqbal memunculkan pandangan ini untuk menciptakan ruang rekonsiliasi antara akal dan agama. Agama bukanlah produk dari argumen rasional murni; filsafat harus mengakui sentralitas agama dalam menguji pengalaman beragama (Masud 2007, 13).

Pertanyaan muncul, apakah pengetahuan intuitif cukup menjadi dasar espitemologi Islam dalam persoalan metafisika? Al-Ghazâlî menjawab iya, sedangkan Iqbal menolak. Di mata Iqbal, al-Ghazâlî melakukan kesalahan ketika memilih pengalaman mistik yang intuitif sebagai satusatunya jalan menyibak wujud Tuhan. Kesalahan al-Ghazâlî adalah ketika ia menyatakan bahwa akal dan intuisi tidak saling berinteraksi dan tidak dapat disandingkan. Sebaliknya, Iqbal melihat kedua metode pengetahuan itu justru saling melengkapi. Iqbal menegaskan bahwa pengetahuan intuisi harus sejalan dengan metode pengetahuan rasional. Rasio dan intuisi tidak dapat dipisahkan. Materi (fisik) dan spiritual (metafisik) merupakan alat penting bagi intuisi meskipun intuisi menyatakan bahwa wujud Tuhan dapat dirasakan secara langsung. Meskipun ditengarai ada konflik antara akal dan intuisi, atau lebih tepatnya antara pengetahuan modern dan agama, Iqbal optimis bahwa keduanya dapat disandingkan. Harmoni antara agama dan sains merupakan prasyarat agar pengalaman spiritual mengambil peran di tengah zaman yang kental dengan kultur rasional dan positivistik.

Bagaimana cara mengharmoniskan sains dan spiritualitas? Menurut Iqbal, langkah pertama, pemikiran saintifik harus dibersihkan dari pemikiran filsafat zaman pra-sains. Langkah berikutnya, dimunculkan sikap kritis dalam menafsirkan agama. Pengalaman beragama merupakan proses dinamis seseorang dalam mensintesiskan sisi-sisi parsial yang kontradiktif dari realitas materi di luar dirinya. Ia mengingatkan bahwa keyakinan beragama seseorang dibentuk oleh pengalaman yang diperolehnya. Selama ini, hubungan keluarga, norma budaya, dan tradisi memberi pengaruh 
besar pada pembentukan keyakinan beragama seseorang dibanding dengan pengalaman pribadinya. Padahal keyakinan beragama yang matang justru datang dari pengalaman beragama seseorang (Iqbal 1986, xxi).

Iqbal menyadari, di tengah masyarakat modern, sulit ditemukan individu yang memiliki keimanan yang didasarkan pada pengalaman pribadi. Fenomena ini, dalam pengamatan Iqbal, karena manusia modern terbiasa dengan cara berpikir logis, sehingga manusia modern kurang peka terhadap pengalaman spiritualnya sendiri. Bahkan, dikarenakan pengalaman spiritual terlihat seperti ilusi, manusia modern bersikap curiga terhadapnya. Di masa lampau, tokoh-tokoh tasawuf mampu memperlihatkan kemampuan luar biasa dalam mengembangkan latihan spiritual sehingga tercipta evolusi pengalaman beragama. Akan tetapi menurut Iqbal, metode ini tidak cocok lagi di zaman modern. Alasannya, zaman modern membutuhkan cara beragama yang saintifik (Iqbal 1986, xxi). Iqbal mengakui, pemikiran modern gagal menyadari pengalaman spiritual karena spiritualitas hanya dipahami secara objektif. Akibatnya, sains yang identik dengan Barat kehilangan kemampuan menangkap kesadaran religiusitas (Iqbal 1986, 5). Sementara manusia Timur berpusat pada hati dan cinta (Raja 2008, 39).

Pembahasan di atas memperlihatkan betapa sains di mata Iqbal dapat membantu dalam memperkuat argumen wujud Tuhan dan mempertahankan pemikiran keagamaan dari ancaman filsafat materialisme dan ateisme. Dengan membersihkan pemikiran agama dari konsep yang tidak berbasis sains, pemikiran keagamaan memperoleh kemampuan untuk menjelaskan secara rasional tentang wujud Tuhan. Sebagai seorang filsuf, Iqbal membongkar epistemologi agar Islam berkesesuaian dengan sains modern. Iqbal memosisikan pengalaman beragama sebagai pintu menyibak wujud Tuhan. Tentu saja pandangan Iqbal ini berbeda dengan pandangan Bediuzzaman Said Nursi.

\section{Pendekatan Bediuzzaman Said Nursi}

Bediuzzaman Said Nursi merupakan salah satu pemikir yang ikut meramaikan jagat perdebatan tentang wujud Tuhan. Selain menghadirkan tafsir kontemporer, Nursi menyumbang metode orisinil dalam perdebatan tersebut (Zubaidi 2015; Coruh 2017). Metode yang dipakai adalah argumen terbalik. Caranya, Nursi memunculkan kasus terlebih dahulu, kemudian mengeluarkan bantahannya dengan mengajukan argumen kemustahilan. Untuk memperkuat metode ini, Nursi menggunakan argumen desain dan 
keteraturan alam. Secara umum argumen Nursi ini masuk ke dalam kategori argumen teleologi. Untuk memudahkan pembaca, gaya penyampaian Nursi menggunakan cerita, dialog, analogi, argumen kemustahilan, dan argumen keteraturan alam dengan menggunakan perkembangan sains terbaru. Di samping itu, Nursi menggunakan asmấ alhusnâ untuk memperkuat argumen wujud Tuhan yang ia sampaikan.

Dalam argumen pembuktian wujud Tuhan, Nursi menggunakan bentuk cerita. Ia memunculkan beberapa tokoh imajiner. Seringkali ia menggunakan cerita tentang dua orang teman. Tokoh-tokoh cerita tersebut jarang diberi nama. Tokoh pertama biasanya mewakili cara pandang Nursi, sedangkan tokoh kedua mewakili cara pandang ateis (Ozalp 2016, 192). Dalam satu sesi cerita, Nursi berkisah tentang dua orang teman yang masing-masing mewakili dua cara pandang filsafat terhadap alam. Orang pertama mewakili pemikiran kelompok teis beserta teori penciptaan, sementara orang kedua mewakili kelompok ateis beserta teori evolusi. Ateisme merupakan pandangan ketuhanan filsafat materialisme dan filsafat naturalisme. Suatu saat dua orang teman ini tersesat di sebuah kota asing. Mereka melihat kota yang tertata rapi. Si penganut teisme terpesona dengan keteraturan dan ketertataan kota. Ia berpikir, pastilah ada orang yang mengatur semua itu. Kota ini pasti memiliki pemimpin. Rumah-rumah yang megah itu pasti ada pembuatnya, dan istana indah itupun dipastikan ada sosok arsiteknya. Mari kita temui mereka, ajak si teis. Si ateis berkata: "Tunjukkan bukti kepadaku adanya penguasa dan pengatur kota ini." Si teis, sebagai representasi pemikiran Nursi, lantas mengungkapkan sejumlah argumen tentang adanya pengatur kota dengan menyebutkan beberapa bukti (Nursi 2005, 115-19). Dalam cerita ini, Nursi hendak mengungkapkan bahwa Tuhan adalah penguasa dan pengatur alam ini. Teknik penggunaan cerita seperti ini dimaksudkan agar mudah dipahami, bahkan oleh mereka yang hanya memiliki kapasitas intelektual terbatas. Cara menghadirkan argumen wujud Tuhan dengan cara populer semacam itu terbukti sukses, bahkan untuk topik rumit sekalipun seperti topik tentang akhirat dan kebangkitan.

Selain menggunakan cerita, Nursi menggunakan dialog. Salah satu dialog untuk pembuktian Tuhan sebagai pemilik alam semesta, Nursi mengetengahkan percakapan dua orang yang tiba di sebuah kota. Mereka melihat pintu-pintu rumah tidak terkunci dan benda berharga terlihat di mana-mana. Orang pertama memunguti benda-benda berharga karena ia berpikir rumah tersebut tidak mempunyai pemilik. Sedangkan orang kedua 
berpendapat, mereka berdua harus menghargai dan memperlihatkan rasa hormat kepada pemiliknya dengan tidak memungutinya karena pastilah ada pemilik benda tersebut meskipun tidak diketahui entah di mana. Namun, orang pertama bersikukuh pada sikapnya dengan alasan ia tidak melihat satu orang pun. Lalu orang kedua mengeluarkan argumen tentang adanya sang pemilik. Dari dialog kedua orang tersebut, Nursi hendak bercerita bahwa alam semesta juga mempunyai pemilik, dan hal tersebut adalah bukti wujud Tuhan (Nursi 2005, 20).

Cara dialog memiliki beberapa manfaat. Pertama, argumen wujud Tuhan lebih mudah dipahami, apalagi disertai perumpamaan yang sering dijumpai oleh masyarakat, seperti kota, bangunan, atau alam semesta, sehingga argumen ini dapat ditangkap oleh pembaca awam. Kedua, dengan cara tersebut Nursi dapat menggabungkan beberapa argumen sekaligus untuk menghasilkan efek persuasi yang lebih kuat. Ketiga, Nursi meniru gaya Alquran, yaitu seakan-akan seluruh kosmos berbicara (Turner 2013, 10). Cara meniru gaya Alquran ini dirasa cukup efektif. Nursi lebih perduli dengan efek persuasi daripada mengikuti pola logika seperti mutakallimûn yang dikenal berbelit-belit. Keempat, Nursi mengajak pembaca untuk mempertanyakan secara kritis pemikiran para filsuf yang menolak wujud Tuhan (Ozalp 2016, 193).

Selain menggunakan dialog, Nursi menggunakan analogi untuk membantah pemikiran kelompok naturalis yang mengatakan bahwa segala sesuatu lahir dengan sendirinya. Dalam tulisannya, Nursi menghadirkan analogi tentang sel tubuh manusia. Tubuh manusia terdiri dari sel-sel yang bekerja tiada henti. Sel mengetahui posisinya agar tubuh dapat berfungsi. Semua sel tahu di mana harus tinggal. Sel-sel yang dibutuhkan oleh mata berada pada lokasinya. Sesama sel tidak saling berebut posisi. Selain itu, jika dikatakan tubuh manusia terbentuk dengan sendirinya, maka harus ada cetakan yang bisa menghasilkan sel-sel tubuh. Karena cetakan tersebut tidak ada, tubuh manusia pastilah produk dari satu Sosok Kreatif (Nursi 2004, 298). Ilmuwan biologi dapat saja membantah argumen Nursi ini dengan mengatakan bahwa makhluk hidup membentuk dirinya melalui replikasi template DNA. Apakah tanggapan ini meruntuhkan argumen Nursi? Secara sepintas tanggapan ini tampak meruntuhkan argumen Nursi. Akan tetapi substansi argumen tersebut, ternyata terbukti tidak. DNA tersusun dari milyaran kode. Dapatkah DNA dibuat oleh dirinya sendiri? Nursi pasti akan mengatakan, di situlah kemustahilan itu berada. Misteri tentang 
bagaimana sel-sel bergabung untuk kemudian melahirkan kehidupan, hingga saat ini masih belum terjawab oleh sains modern (Ozalp 2016, 200).

Argumen kemustahilan merupakan salah satu teknik Nursi untuk membalik argumen lawan. Nursi menyerang filsafat materialisme yang membuang jauh-jauh penjelasan spiritual dan supranatural dalam penciptaan alam. Nursi berusaha mematahkan argumen naturalisme dengan memperlihatkan beberapa kemustahilan. Misalnya, untuk membantah pemikiran bahwa 'sebab' dianggap sebagai pencipta bagi benda dan makhluk, Nursi mengajukan analogi tentang toko farmasi yang dipenuhi dengan obat-obatan. Selain memiliki khasiatnya masing-masing, setiap obat memiliki kualitas penyembuhannya sendiri-sendiri. Kualitas penyembuhan obat tersebut diperoleh dari bahan tertentu dengan takaran yang pas sesuai dengan resep yang akurat. Jika dicampur secara serampangan, maka obat tersebut justru akan menjadi racun. Oleh karenanya mustahil jika percampuran dan takaran obat terjadi secara kebetulan tanpa campur tangan seorang ahli yang mengatur komposisinya. Begitu juga mustahil apabila makhluk hidup di muka bumi tercipta secara kebetulan ketika ternyata setiap makhluk hidup tersusun dari berbagai unsur kimia dengan takaran yang sangat pas. Makhluk hidup yang terdiri dari berbagai unsur kimia ini pastilah diproduksi oleh pemilik pengetahuan yang Maha Tahu (Nursi 2004a, 103).

Langkah berikutnya, Nursi menggunakan argumen keteraturan alam. Secara umum, inti dari argumen keteraturan alam dapat didefinisikan sebagai pengaturan oleh Tuhan (Yaran 2003, 33). Bentuk logikanya dapat diringkas sebagai berikut: ditemukan keteraturan pada alam; keteraturan ini memerlukan sifat-sifat tertentu seperti maha kuasa; tidak satupun entitas di alam ini memiliki sifat tersebut; karena itu, pastilah hanya Tuhan yang memiliki sifat tersebut. Untuk memperkuat premis tersebut, Nursi menggunakan pembuktian sebagaimana ulama klasik dengan menggunakan argumen hikmah, 'inâyah, dan ikhtirâ'. Penjelasan ini dapat ditemukan dalam buku Ray ke-7 berjudul Âyât al-Kubrâ (tanda-tanda besar). Nursi menegaskan bahwa sosok yang mengontrol hujan, misalnya, pastilah sosok yang mengatur keseluruhan alam semesta (Nursi 2004b, 148).

Untuk memperkuat argumen wujud Tuhan, Nursi bercerita tentang orang bodoh yang menjumpai tempat latihan militer. Si bodoh mengamati sekelompok tentara yang sedang membentuk barisan dengan teratur dan kompak. Mereka bergerak secara serentak. Para tentara seakanakan seperti satu tubuh. Si bodoh menyangka, kekompakan itu muncul 
karena semua tentara diikat dengan satu tali sehingga mereka melakukan gerakan yang serempak dalam waktu yang bersamaan. Si bodoh tidak tahu, ternyata, ada seorang komandan yang memberi aba-aba perintah. Alam, lanjut Nursi, adalah seperti tentara raksasa yang berada di bawah satu komando (Nursi 2004a, 681).

Untuk memperkokoh argumen wujud Tuhan, Nursi membuat perbandingan di dunia binatang. Beberapa binatang memiliki kekuatan besar, salah satunya singa. Sementara itu ada binatang lemah seperti ulat buah. Rasio keberhasilan berburu singa adalah 40 persen. Hal ini berarti, singa harus bekerja sangat keras dalam berburu agar bisa bertahan hidup. Sebaliknya, binatang yang amat lemah seperti ulat buah mengeluarkan usaha amat sedikit untuk memperoleh makanan. Sang Pencipta menempatkan ulat buah tepat di pusat makanan. Semakin kuat seekor binatang, maka akan semakin lebih keras untuk mendapatkan makanan. Sedangkan binatang yang lemah, akan mendapat makanan dengan lebih mudah. Ketersediaan makanan dan kemampuan untuk mendapatkan makanan terbukti amat proporsional. Sang Pencipta mendesain alam dan binatang sedemikian rupa sehingga usaha setiap binatang untuk mendapatkan makanan sesuai dengan kapasitasnya.

Untuk menggambarkan argumen keteraturan alam, Nursi menggunakan cerita tentang seorang pengelana yang berjalan menembus jagat raya untuk menguji segala sesuatu bekerjasama satu sama lain sehingga tercipta keteraturan. Sang pengelana menjumpai beberapa hal: bumi, bintang, atmosfer, planet, sungai, samudera, gunung, padang rumput, pohon, dan binatang. Ketika sang pengelana turun ke langit bawah, ia mendapati atmosfer berfungsi untuk menjaga keberlangsungan makhluk hidup di muka bumi. Udara untuk bernafas. Ruang udara untuk mentransmisikan sejumlah gelombang suara secara bersamaan tanpa terjadi kekacauan. Angin membantu menebarkan benih tanaman. Air hujan menyirami tumbuhan dengan kecepatan yang akurat sehingga tanaman tidak rusak dan bisa hidup. Tentu saja air hujan tidak mampu mengetahui kebutuhan makhluk bumi, sebab itu manfaat air ini hanya dapat disimpulkan sebagai bagian dari sifat pemurah Tuhan (Nursi 2004b, 149).

Menurut Nursi, keteraturan alam merupakan keajaiban Tuhan. Alam adalah kitab suci dalam bentuk fisik (Khamami 2015a, 65). Alam adalah buku yang berisi hukum tentang cara kerja Tuhan. Selain itu, alam sendiri merupakan sebuah karya seni. Alam tidak bisa menjadikan dirinya sebagai si pembuat seni itu sendiri. Alam tidak menjadi pencipta bagi 
dirinya. Alam adalah penerima pasif. Kesimpulan Nursi, karena semua teori kelompok naturalis dan ateis tentang asal mula alam semesta tidak bisa memberi penjelasan yang memuaskan, justru terlihat mustahil, jadi keberadaan Tuhan adalah sebuah kepastian (Nursi 2004a, 305). Semua penjelasan ini tampak terlalu sederhana jika dipandang dari sudut sains kontemporer. Harap dicatat, penjelasan Nursi ini merefleksikan pengetahuan sains akhir abad kesembilanbelas. Kendati demikian, Thomas Michel mengakui bahwa perkembangan ilmu pengetahuan kontemporer tentang kosmologi, alam, dan biologi justru semakin memperkuat argumen Nursi (Michel 2013, 242-7).

Nursi sadar bahwa untuk membuktikan wujud Tuhan dirasa lebih mudah dilakukan dibanding membuktikan ketakwujudan Tuhan. Keberadaan Tuhan jauh lebih masuk akal jika dibandingkan dengan argumen yang menolak Tuhan. Nursi menegaskan, wujud Tuhan tidak hanya wajib ada (wâjib al-wujûd), tetapi ketakwujudan Tuhan adalah sesuatu yang mustahil. Nursi secara efektif membalik argumen yang menolak wujud Tuhan dengan menghadirkan argumen kemustahilan. Pendekatan Nursi ini tidak hanya memperkuat wajibnya wujud Tuhan, tetapi juga untuk menyerang argumen yang menolak wujud Tuhan. Turner mengakui bahwa argumen Nursi ini memiliki keistimewaan dan kekhasan tersendiri (Turner 2013, 11). Pembuktian dengan cara terbalik ini merupakan ciptaan orisinil Nursi meskipun ia sendiri tidak menyematkan istilah tersebut. Yaran menyinggung argumen ciptaan Nursi ini namun tanpa menyematkan nama (Yaran 2003, 134-6). Dalam disertasi di Durham University, Hakan Gok juga tidak melabeli dengan istilah tertentu (Gok 2014, 102-42). Sedangkan Mehmet Ozalp menyematkan argumen Nursi tersebut dengan istilah "default argument" (Ozalp 2016, 179).

Menariknya, di setiap penghujung penjelasan argumen keteraturan alam, Nursi selalu menulis kalimat: lâ ilâha illa Allâh al-wâjib al-wujûd al wâhid al-ahad alladhî dalla 'alâ wujûb wujûdiĥ̂ fî wahdah. Gaya penulisan semacam ini terhitung unik, tidak hanya untuk mengungkapkan pembuktian wujud Tuhan, tetapi juga untuk mengaitkan dengan keesaan Tuhan (Ozalp 2016, 206). Bagi Nursi, sifat Tuhan seperti Maha Esa amat dibutuhkan untuk berjalannya keteraturan alam. Nursi mengakui bahwa keesaan Tuhan dapat dibaca pada alam. Kebanyakan dapat dilihat dengan mata, sedangkan sisanya hanya dapat dibaca melalui akal. Penjelasan Nursi ini juga memiliki kesamaan dengan argumen 'inâyah yang dimunculkan oleh Ibn Rushd (1126-1198 M). Satu hal yang berbeda dari Ibn Rushd, 
Nursi menggunakan kata "ta'âwun" (saling membantu). Nursi mengungkapkan bahwa semua makhluk hidup saling membantu. Meskipun tampaknya makhluk hidup saling berkompetisi mempertahankan hidup masing-masing, namun dalam kenyataannya mereka diatur untuk saling membantu satu sama lain (Nursi 2004b, 195). Misalnya, hujan dan tanaman dibuat untuk menopang hidup binatang. Saat menjadi bangkai, binatang menjadi pupuk agar tanaman bisa hidup (Nursi 2005, 734).

Argumen keteraturan alam mendapat penguatan dari Nursi melalui pembacaan terhadap asmấ al-husnâ. Tuhan memiliki nama-nama

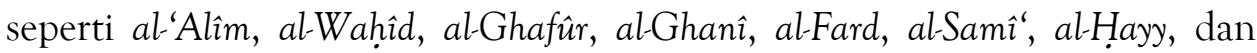
seterusnya. Tuhan yang menyandang nama al'Alim (Maha Tahu) menciptakan beragam tanaman dari unsur yang sama. Meskipun di alam ini hanya ada 114 unsur kimia, namun tercipta jutaan tumbuhan dari unsur dasar ini. Kendati semua bibit tersusun dari komposisi yang hampir sama, namun ketika dua biji ditanam, keduanya tumbuh beda. Nursi mengajukan pertanyaan, bagaimana mungkin bisa tercipta tanaman berbeda-beda dari komposisi kimiawi yang sama dan satu tanah yang sama? Mungkinkah yang menjadikan keberagaman tersebut adalah tanah? Ataukah bibitnya? Pastilah ada sosok cerdas di balik semua kerja biologi tersebut. Karena bibit dan tanah tidak memiliki kecerdasan, maka hanya Tuhan saja yang menciptakan beragam tanaman (Nursi 2004c, 1356).

Contoh penggunaan asmấ al-husnâ kedua adalah nama Tuhan al'Adl (Maha Penyeimbang). Di muka bumi berlaku keseimbangan ekologi dengan jumlah kelahiran dan kematian yang berimbang. Hal ini terjadi agar tidak hanya segelintir spesies saja yang menguasai planet bumi. Di dalam tubuh manusia dan binatang juga berlaku hal yang sama, proses osmosis menjadikan segala sesuatu menjadi imbang. Keseimbangan terjadi di seluruh bumi dan alam semesta. Proses keseimbangan alam yang menakjubkan ini tidak mudah dijelaskan hanya dengan teori sebab-akibat. Agar keseimbangan bisa berjalan dengan lancar, dibutuhkan pengetahuan yang tidak terbatas. Proses tersebut dapat berjalan hanya jika diatur oleh Sang Pengatur Alam, yaitu Tuhan (Nursi 2004a, 561-4).

Berikutnya nama Tuhan al-Ahad, Nursi menggunakannya untuk menyatakan bahwa Tuhan pastilah esa dan tunggal. Kenapa tidak banyak Tuhan? Untuk menjawab pertanyaan ini, Nursi menggunakan analogi tentang kepala desa. Sebuah desa membutuhkan satu kepala desa. Nursi menegaskan bahwa pemimpin desa haruslah satu orang. Sebaliknya, jika 
penguasa desa berjumlah lebih dari satu, maka akan terjadi konflik, dan akhirnya merusak jalannya pengelolaan (Nursi 2005, 20). Begitu juga dalam pengelolaan alam semesta.

Dalam mengungkapkan kebersihan alam, Nursi merujuk pada alQuddûs (Maha Suci) untuk menjelaskan bahwa Tuhan menjadikan alam dan bumi tetap terjaga bersih. Analogi yang dipakai adalah pabrik. Pabrik beroperasi terus-menerus, memproduksi barang, dan menghasilkan ampas dan kotoran. Pabrik akan cepat rusak bila tidak segera dibersihkan. Begitu juga bumi dan alam beroperasi seperti halnya pabrik, bekerja terus-menerus dan menghasilkan sampah dan kotoran. Sampah di ruang angkasa tersapu bersih seiring berjalannya waktu sehingga ruang angkasa tetap terjaga kebersihannya. Atmosfer bersih dari substansi yang mengganggu. Jika sampah dan kotoran yang dihasilkan oleh makhluk bumi dan semua bangkai hewan dan sisa tumbuhan tidak dibersihkan dari muka bumi, maka bumi akan dipenuhi dengan bangkai, sampah dan kotoran. Namun, bumi selalu tampak bersih. Begitu juga di dalam tubuh manusia, sel darah merah juga membersihkan tubuh dari karbon dioksida. Tumbuhan dan binatang memiliki mekanisme untuk membersihkan dirinya sendiri. Semua proses pembersihan tersebut terlihat amat menakjubkan (Nursi 2004a, 5567).

Sejumlah orang mengkritik, ternyata, ditemukan kecacatan pada alam. Contohnya, retina mata binatang mamalia menghadap ke belakang. Hal ini merupakan bukti tidak adanya pendesain yang cerdas. Nursi menjawab, filsafat materialisme dan filsafat naturalisme gagal memahami makna alam semesta karena mereka melihat alam hanya pada apa yang nampak. Nursi memunculkan dua cara pembacaan terhadap alam. Pertama, $m a$ 'nâ ismî, yaitu makna nominal, atau makna yang nampak dari sebuah benda. Kedua, ma'nâ ḥarfî, yaitu makna indikatif, atau makna tidak langsung dari benda. Misalnya, ketika seseorang melihat sebuah bunga, lalu kagum dengan kecantikan bunga tersebut, jika ia mengatakan "bunga ini adalah bunga yang cantik," maka ia melihat kecantikan tersebut secara nominal (atau, ma'nâ ismî). Sedangkan jika ia berkata "bunga ini diciptakan cantik," maka ia mengakui bunga tersebut sebagai karya dari Sang Pendesain (Tuhan), dan melihatnya secara indikatif ( $m a^{\prime} n a ̂$ harfî). Nursi mengkritik filsafat materialisme yang melihat alam semesta semata-mata dari kacamata nominal. Sedangkan Nursi memandang alam semesta melalui kacamata 
ma'nâ harfî yaitu cara pandang yang merefleksikan keagungan Sang Pencipta (Khamami 2015a, 59).

Seringkali dalam mengungkapkan argumen wujud Tuhan, Nursi menggunakan perumpamaan dari temuan sains terbaru. Misalnya, Nursi membuktikan wujud Tuhan dengan ilmu kimia. Organisme terdiri dari unsur magnesium, besi, oksigen, dan hidrogen. Pada dasarnya, kebanyakan unsur kimia saling bermusuhan satu sama lain. Beberapa dari unsur tersebut bersifat reaktif terhadap unsur lain. Secara teknis, penggabungan unsur-unsur tersebut dapat menghasilkan reaksi kimia seperti terbakar atau meledak. Namun, semua unsur tersebut bergabung secara berdampingan pada organisme. Salah satu contoh terbaik dari gabungan unsur tersebut adalah air. Molekul air terdiri dari hidrogen dan oksigen yang bergabung secara alamiah di alam. Hidrogen adalah gas yang mudah terbakar, sedangkan oksigen adalah unsur untuk pembakaran. Tetapi dalam formula air, dua unsur yang reaktif ini dapat saling bergabung membentuk satu substansi baru, yaitu air. Nursi berpendapat, hanya Sosok Pencipta Cerdas yang mampu melakukan penggabungan tersebut.

Nursi mengkritik kelompok naturalis yang mengatakan bahwa 'sebab' menjadi pencipta. Maksudnya, sebuah benda dimunculkan oleh 'sebab'. Para pengikut aliran atomisme, seperti Demokritus (460-370 SM), berpandangan bahwa setiap kejadian di alam dapat dijelaskan melalui sains. Demokritus menolak peran Tuhan. Ia menegaskan bahwa alam adalah hasil dari proses 'sebab-akibat' yang terjadi secara kebetulan. Cara Demokritus ini berbeda dari para penganut aliran kosmologis seperti Aristoteles yang berusaha menjelaskan melalui Sang Penggerak Pertama, atau Penyebab Pertama. Menurut Nursi, postulat ini tidak bisa diterima dan mustahil. Pendapat yang mengatakan bahwa keteraturan alam terjadi karena sebuah kebetulan adalah salah. Nursi mengajukan pertanyaan, apakah kita menerima jika disebutkan bahwa obat-obatan di farmasi muncul secara kebetulan? Jawabannya adalah tidak (Gok 2014, 111-2). Nursi mengakui bahwa 'sebab' ada di mana-mana tersebar di alam ini, dan orang awam dapat saja terjatuh dalam kesalahan dengan menyangka 'sebab' sebagai penyebab utama. Akan tetapi, menurut Nursi, sebab-sebab tersebut sejatinya hanyalah tabir yang menyembunyikan Aktor sesungguhnya, yaitu Tuhan.

Nursi mengakui bahwa 'sebab' menjadi alasan di balik perputaran alam semesta. Menurut Nursi, semua 'sebab' hanyalah pelaksana atas perintah Penguasa alam ini. Sebagai penganut teis, Nursi mempercayai 
bahwa Tuhanlah pemberi perintah tersebut. Cara pandang Nursi ini berangkat dari sudut pandang ma'nâ harfî. Di balik alam ini, Nursi melihat tanda adanya Sang Maha Kuasa. Akan tetapi Nursi tidak sepakat dengan konsep penciptaan dari ketiadaan (ex-nihilo). Ia berpendapat bahwa konsep penciptaan dari ketiadaan bertentangan dengan sifat Tuhan. Penciptaan alam, menurut Nursi, adalah pemindahan dari alam yang tidak terlihat menjadi alam yang memiliki wadah. Sejak semula benda-benda sudah ada di alam lain, yaitu alam Tuhan. Benda tersebut semata-mata diberi badan fisik saat dipindah ke alam semesta ini (Nursi 2004b, 857).

\section{Komparasi antara Muhammad Iqbal dan Bediuzzaman Said Nursi}

Iqbal dan Nursi memiliki kesamaan, yaitu melakukan perlawanan terhadap ateisme dan filsafat materialisme. Persamaan berikutnya, kedua pemikir ini sama-sama menggunakan sains untuk memperkuat wujud Tuhan. Sama seperti Nursi yang menggunakan sains seperti penjelasan di atas, Iqbal juga menggunakan pemikiran sains modern untuk membuktikan bahwa Tuhan ada. Ia menyatakan bahwa pemikiran sains modern tentang materi, ruang dan waktu dapat dipakai untuk menangkap wujud Tuhan; yaitu bagaimana fisika kontemporer memahami materi; biologi memahami hidup; dan psikologi memahami kesadaran (Iqbal 1986, 23-25; Masud 2007, 14). Penjelasan fisika modern tentang perkembangan alam digunakan oleh Iqbal sebagai pijakan untuk membaca ulang hubungan antara alam dan Tuhan meskipun ilmu fisika tentang alam telah mengalami reduksi sejak Newton. Dalam menata argumennya, Iqbal memakai pendapat sejumlah filsuf untuk memperkuat pemikirannya. Di antara mereka adalah Berkeley dan Whitehead. Jika fisika klasik menyatakan bahwa alam bersifat kekal, tidak bernyawa (matter) dan berada di ruang (space), Berkeley mengkritik teori tersebut. Pemahaman semacam itu, menurut Berkeley, melahirkan jurang yang memutus hubungan antara subjek yang mengetahui (akal) dan objek yang diketahui (materi). Whitehead memperkuat pendapat Berkeley dengan mengatakan bahwa alam bukanlah entitas statis yang berada di ruang kosong, tetapi merupakan sebuah struktur yang memiliki karakter kreatif dengan sifat berubah terus-menerus. Iqbal mengamini kedua pendapat tersebut (Iqbal 1986, 28).

Dengan memakai sains modern, untuk contoh lain, Iqbal menggunakan biologi untuk memetakan kesalahan pada logika argumen teleologi. Ilmu biologi menolak anggapan kelompok materialis yang mengatakan bahwa alam semesta tidak berubah, statis dan sudah tercetak, 
sebuah konsep yang lahir dari warisan fisika Newton. Siapa pun yang melihat alam akan mendapati bahwa alam mengalami pertumbuhan dan perubahan. Sementara itu, karakteristik pembeda antara organisme dan mesin adalah kemampuan berkembang biak. Organisme tidak semata-mata mengikuti pola tertentu agar dapat bertahan hidup, tetapi juga memunculkan pola baru. Organisme yang dapat bertahan hidup adalah organisme yang dapat merespon secara kreatif tantangan alam. Sementara mesin hanya bisa mengulang-ulang gerak yang telah terpola. Mesin tidak dapat memunculkan pola baru. Iqbal berkesimpulan bahwa berbagai upaya untuk menjelaskan perilaku organisme dalam terma mekanik telah gagal (Iqbal 1986, 44). Di mata Iqbal, argumen ontologi dianggap gagal sebagaimana halnya argumen kosmologi dan teleologi. Ia mengusulkan untuk menggunakan pengamatan saintifik dan filsafat. Iqbal membongkar argumen wujud Tuhan dari aspek epistemologi, dan ia menawarkan argumen pengalaman beragama.

Berbeda dari Iqbal yang membongkar argumen wujud Tuhan dari aspek filsafat dan mempertanyakan argumen teleologi, Nursi justru menggunakan argumen teleologi dengan memanfaatkan perkembangan sains pada masa itu untuk menjelaskan argumennya. Pilihan Nursi ini muncul di tengah gelombang filsafat materialisme dan filsafat naturalisme di Turki pada akhir abad kesembilanbelas yang menyerang keimanan masyarakat muslim meskipun menurut Colin Turner, argumen Nursi ini tidak benar-benar argumen wujud Tuhan sebagaimana dipahami dalam dunia filsafat (Khamami 2015b, 8). Turner beralasan karena Nursi berangkat dari iman, kemudian menggunakan argumen teleologi tersebut untuk membantah lawan demi memperkuat iman yang sudah ada (Turner 2013, 10).

Perbedaan berikutnya, ketika Iqbal menggunakan pendekatan filsafat yang dipelajari dari ilmuwan Barat, Nursi memanfaatkan kekayaan khazanah Islam dengan menghadirkan kembali argumen wujud Tuhan dalam bahasa sederhana agar mudah dicerna masyarakat awam. Argumen yang dipakai Nursi merupakan pengembangan dari argumen warisan ulama terdahulu, salah satunya al-Ash'arî dan Ibn 'Arabî (Koca 2016). Nursi mengkritisi pendekatan mutakallimûn dalam pembuktian wujud Tuhan. Nursi sadar, pembuktian dengan menggunakan logika sebagaimana mutakallimûn merupakan cara pembuktian yang terlalu abstrak, berbelitbelit, dan tidak menarik di mata orang awam. Meskipun sempat beberapa kali menggunakan argumen kosmologi dan argumen ontologi di dalam 
tulisannya, pada periode-periode berikutnya Nursi menghindari penggunaan argumen hudûth dan imkân, dua argumen yang masuk dalam kategori argumen kosmologi dan argumen ontologi. Nursi menggunakan argumen hudûth dan imkân sebanyak dua kali di dalam buku Risale-i Nur. Itu pun dibahas secara sepintas. Keengganan Nursi menggunakan argumen kosmologi dan argumen ontologi didasari atas kebutuhan masyarakat. Ia bermaksud memperkuat keimanan mereka di tengah arus modernisme, sekulerisme, materialisme, dan positivisme di Turki (Khamami 2015b, 10).

Pendek kata, meskipun keduanya sama-sama menggunakan sains sebagai dasar argumentasinya, namun kedua pemikir ini menggunakan pendekatan berbeda. Nursi menggunakan temuan terbaru sains pada zamannya untuk memperkuat argumen yang ia munculkan, sedangkan Iqbal menggunakan epistemologi sains untuk wujud Tuhan. Ketika Nursi menggunakan argumen wujud Tuhan yang diwarisi dari para ulama terdahulu untuk menghantam serangan kelompok ateisme dan penganut materialisme, Iqbal menggunakan filsafat yang dipelajari dari ilmuwan Barat untuk untuk memperkuat wujud Tuhan dari sisi filsafat. Berbeda dari Iqbal yang menolak teleologi, sebagai ulama dan pendakwah, Nursi sengaja memilih argumen teleologi agar mudah dipahami masyarakat awam. Nursi menggunakan bahasa yang sederhana untuk menarik masyarakat awam dengan menghadirkan argumen teleologi dalam bentuk cerita, dialog, analogi, argumen keteraturan alam, dan argumen kemustahilan.

\section{Simpulan}

Di tengah kemajuan sains, posisi agama, terutama wujud Tuhan, menghadapi ancaman dari ateisme dan filsafat materialisme. Tatkala penganut filsafat materialisme melihat realitas hanya melalui kacamata empirisme, nilai keagamaan tereduksi. Sebagai seorang Muslim, Muhammad Iqbal menyadari bahwa Islam berada di pusaran zaman yang dipenuhi dengan cara berpikir saintifik yang materialistis dan positivistik. Iqbal berupaya menjawab tantangan yang dihadapi agama Islam di tengah perkembangan sains abad kesembilanbelas. Ia menentang konsep alam yang digagas oleh para pengikut materialisme. Salah satunya adalah mempertahankan wujud Tuhan dengan argumen pengalaman beragama. Inti argumen Iqbal adalah bahwa wujud Tuhan dapat dibuktikan keberadaan-Nya.

Di pihak lain, serangan kelompok ateis dan penganut filsafat materialisme di Turki pada abad kesembilanbelas menggerakkan 
Bediuzzaman Said Nursi untuk melibatkan diri dalam perdebatan tentang wujud Tuhan. Jika Iqbal membongkar argumen wujud Tuhan dengan pendekatan filsafat, Nursi, sebagai ulama dan pendakwah, menghadirkan argumen wujud Tuhan dengan menggunakan bahasa yang sederhana untuk membentengi iman masyarakat. Dalam pemaparan argumen teleologinya, Nursi menggunakan cerita, analogi, dialog, argumen keteraturan alam, dan argumen kemustahilan. Meskipun kedua pemikir tersebut sama-sama menggunakan sains epistemologi pada Iqbal, dan Nursi pada ontologi, mereka berbeda dalam pendekatan.

\section{Daftar Pustaka}

Aksoy, Nuriye. 2015. "Meeting the Challenges of Modernity as Experienced by Said Nursi, Muhammad Iqbal dan Muhammad Abduh." Tesis. The State University of New Jersey.

Al-Walid, Kholid. 2018. "Takwil Epistemologis Ibn Sînâ atas Surah al-Nûr Ayat 35." Ulul Albab: Jurnal Studi Islam 19(1): 1-24.

Ansari, Mahsheed. 2015. "The Rational and Metaphysical Notions of Prophethood and the Prophet Muhammad in the Thought of Said Nursi and Muhammad Iqbal." Disertasi. Monash University, Australia.

Ansari, Mahsheed. 2017. "Nursi and Iqbal on Mi'raj: The Metaphysical Dimension of the Prophet's Ascension." Australian Journal of Islamic Studies 2(2): 21-41.

Coruh, Hakan. 2017. "Tradition, Reason, and Qur'anic Exegesis in the Modern Period: The Hermeneutics of Said Nursi." Islam and Christian-Muslim Relations 28(1): 85-104.

Craig, William. 2000. The Kalam Cosmological Argument. Oregon: Wipf and Stock Publisher.

Gok, Hakan. 2014. "Said Nursi's Arguments for the Existence of God in Risale-i Nur." Disertasi. Durham University.

Fakhry, Majid. 2004. A History of Islamic Philosophy. New York: Columbia University Press, Longman.

al-Ghazâlî. 1963. Tahâfut al-Falâsifah (The Incoherence of Philosophers). Terj. Sabih Ahmad Kamali. Lahore: Pakistan Philosophical Congress. 
Iqbal, Muhammad. 1986. The Reconstruction of Religious Thought in Islam. Lahore, Pakistan: Institute of Islamic Culture.

Khamami, Akhmad Rizqon. 2015a. "Membangun Peradaban dengan Epistemologi Baru: Membaca Pemikiran Said Nursi." Tsaqafah: Jurnal Peradaban Islam 11(1): 51-70.

Khamami, Akhmad Rizqon. 2015b. "Kontribusi Gerakan Nursi dalam Kebangkitan Islam di Turki.” Islamica: Jurnal Studi Keislaman 10(1): $1-26$.

Koca, Ozgur. 2016. "Causality as a 'Veil': The Ash'arites, Ibn 'Arabî (11651240) and Said Nursi (1877-1960)." Islam and Christian-Muslim Relations 27(4): 455-70.

Maftukhin. 2017. "Reposisi Konsep Ketuhanan: Tanggapan Muhammad Iqbal dan Said Nursi atas Perjumpaan Islam dan Sains.” Episteme: Jurnal Pengembangan Ilmu Keislaman 12(1): 77-102.

Masud, Muhammed Khalid. 2007. "Iqbâl's Approach to Islamic Theology of Modernity." Al-Hikmat 27: 1-36.

Michel, Thomas. 2013. Insights from the Risale-i Nur: Said Nursi's Advice for Modern Believers. New Jersey: Tughra Books.

Mohamed, Yasien. 2006. "The Concept of Predestination and Free Will in Iqbal and Nursi." Afkar 7: 93-120.

Nasr, Seyyed Hossein. 1978. An Introduction to Islamic Cosmological Doctrines. Great Britain: Thames and Hudson.

Nursi, Said. 2004a. The Flashes. Istanbul: Nesil.

Nursi, Said. 2004b. The Rays. Istanbul: Nesil.

Nursi, Said. 2004c. Al-Mathnawi al-Nuri. Istanbul: Nesil.

Nursi, Said. 2005. The Words. Istanbul: Nesil.

Ozalp, Mehmet. 2016. "God and Tawhid in Classical Islamic Theology and Said Nursi's Risale-i Nur.” Disertasi. University of Sydney.

Politis, Vasilis. 2005. Aristotle and the Metaphysics. London: Routledge. 
Raja, Masood A. 2008. "Muhammad Iqbal: Islam, the West, and the Quest for a Modern Muslim Identity." The International Journal of the Asian Philosophical Association 1(1): 33-45.

Turner, Colin. 2013. The Qur'an Revealed: A Critical Analysis of Said Nursi's Epistles of Light. Berlin: Gerlach Press.

Yaran, Cafer S. 2003. Islamic Thought on the Existence of God: With Contributions from Contemporary Western Philosophy of Religion. Washington: Council for Research in Values and Philosophy.

Zubaidi, Sujiat. 2015. "Tafsir Kontemporer Bediuzzaman Said Nursi dalam Risale-i Nur: Studi Konstruk Epistemologi.” Disertasi. Universitas Islam Negeri Sunan Ampel Surabaya. 